\title{
Expression and biological effects of bone morphogenetic protein-15 in the hen ovary
}

\author{
S Elis, J Dupont, I Couty, L Persani ${ }^{1}$, M Govoroun, E Blesbois, F Batellier and P Monget \\ Physiologie de la Reproduction et des Comportements, UMR 6175 INRA-CNRS-Université F Rabelais de Tours, Haras Nationaux, 37380 Nouzilly, France \\ ${ }^{1}$ Institute of Endocrine Sciences, University of Milan, 20122 Milan, Italy \\ (Correspondence should be addressed to P Monget; Email: monget@tours.inra.fr)
}

\begin{abstract}
The bone morphogenetic protein 15 (Bmp15) and growth differentiation factor 9 (Gdf9) genes are two members of the transforming growth factor- $\beta$ superfamily. In mammals, these genes are known to be specifically expressed in oocytes and to be essential for female fertility. However, potential ovarian roles of BMPs remain unexplored in birds. The aim of the present work was to study for the first time the expression of Bmp15 in the hen ovary, to compare its expression pattern with that of Gdf9, and then to investigate the effects of BMP15 on granulosa cell (GC) proliferation and steroidogenesis. We found that chicken Bmp15 and Gdf9 genes were preferentially expressed in the ovary. We showed using in situ hybridization that Bmp15 and Gdf9 mRNAs were specifically localized in oocytes of all ovarian follicles examined. We also
\end{abstract}

demonstrated using real-time quantitative RT-PCR that Bmp15 and Gdf9 expression was maintained during hierarchical follicular maturation in the gerrminal disc region and then progressively declined after ovulation. BMP15 was able to activate Smad1 (mothers against decapentaplegichomolog1) signaling pathway in hen GCs. Moreover, we showed a strong inhibitory effect of BMP15 on gonadotropin-induced progesterone production in hen GCs. This inhibitory effect was associated with a decrease in steroidogenic acute regulatory protein (STAR) level. Taken together, our results suggest that BMP15 may have a key role in the female fertility of birds.

Journal of Endocrinology (2007) 194, 485-497

\section{Introduction}

Recent evidence indicates that bone morphogenetic proteins (BMPs) are expressed in a cell-specific manner in the mammalian ovary, and they play key roles in the regulation of folliculogenesis, ovulation, and corpus luteum functions (Knight \& Glister 2003, Su et al. 2004, Pierre et al. 2005). The Bmp 15 and growth differentiation factor 9 (Gdf9) genes are two members of the transforming growth factor- $\beta$ (TGF- $\beta$ ) superfamily. They are specifically expressed in oocytes and essential for female fertility in several species, including humans, sheep, and mice (for a review, see Juengel et al. 2004). The importance of these factors in mice ovarian function has been confirmed by gene knockout experiments. Female mice lacking the Gdf9 gene are infertile, with follicular growth arrested at the primary stage (Dong et al. 1996), whereas Bmp15 knockout female mice are fertile, with only slight changes in folliculogenesis (Yan et al. 2001). Moreover, partial loss of function of Bmp 15 in ewes leads to an increase in the ovulation rate, whereas mutation leading to complete loss offunction dramatically affects folliculogenesis and fertility in sheep and humans (Galloway et al. 2000, Juengel et al. 2002, Hanrahan et al. 2004, Di Pasquale et al. 2004). These factors could thus affect ovarian function in a species-specific manner (Hashimoto et al. 2005).

The expression pattern of these two genes differs between species, Gdf9 being expressed in primordial follicles in bovine, ovine, and brushtail possum species (Bodensteiner et al. 1999, Eckery et al. 2002) but not in mice. Usually, the Bmp15 gene is not expressed in primordial follicles in mice, sheep, and cattle, whereas it is found in primordial follicles in the brushtail possum (Eckery et al. 2002). Moreover, GDF9 and BMP15 regulate a variety of murin granulosa and theca cell functions in vitro. The BMP15 effects on granulosa cells (GCs) are mediated through activation of several signaling pathways, including the Smad1/5/ 8 (mothers against decapentaplegic homolog 1/5/8) and/or mitogen-activated protein kinase (MAPK) (extracellular signalregulated kinase 1/2, ERK) signaling pathway (Moore et al. 2003, Su et al. 2004). In contrast to BMP4 and BMP2, BMP15 has not been shown to activate the MAPK p38 pathway (Yamaguchi 1995). In rodents, both GDF9 and BMP15 inhibit follicle-stimulating hormone (FSH)-stimulated steroid production by GCs, partly through inhibition of expression of gonadotropin receptors (Otsuka et al. 2000). Indeed, in rat GCs, GDF9 suppresses binding of human chorionic gonadotropin (hCG; Vitt et al. 2000), and BMP15 decreases FSH receptor mRNA expression (Otsuka et al. 2001). This inhibitory effect of BMP15 on FSH-induced progesterone secretion is associated with a decrease in the protein level of steroidogenic acute 
regulatory protein (StAR), an important cholesterol carrier, and two key enzymes of steroidogenesis $3 \beta$ hydroxysteroid dehydrogenase (3 $\beta$-HSD) and P450scc (P450 side chain cleavage; Otsuka et al. 2001). Moreover, GDF9 and BMP15 exert a mitogenic effect in human (Di Pasquale et al. 2004) and rat GCs (McNatty et al. 2005). In birds, oocyte-conditioned medium increased chicken GC proliferation in vitro. This effect is inhibited by GDF9 antibody suggesting that GDF9 also exerts a mitogenic effect in avian GCs (Johnson et al. 2005).

Study of the reproductive physiology of the hen shows numerous specific features which include oviparity and telolecithal oocytes (Gilbert 1971). There are several differences between mammalian and hen ovarian folliculogenesis. The ovary of reproductively active hens contains small pre-hierarchical follicles and maturing preovulatory follicles showing a hierarchy according to their size (F6-F1; Etches \& Petitte 1990). In laying hens, ovulation may occur almost every day, the largest follicle (F1) filled with yolk, being ovulated first, then the second largest (F2) the following day, and so on until a pause interrupts the sequence of ovipositions, generating successive multiple series of ovipositions. The avian oocyte, which can reach the size of $40 \mathrm{~mm}$ in diameter before ovulation, consists of a large amount of yolk and a structure called the germinal disc. The germinal disc is a white plaque about 3-4 $\mathrm{mm}$ in diameter on the surface of the oocyte. It contains the nucleus and $99 \%$ of organelles of the oocyte even though it occupies $<1 \%$ of oocyte volume (Yao \& Bahr 2001). Structurally, and therefore functionally, the germinal disc is equivalent to the mammalian oocyte. Before ovulation, the germinal disc is closely associated with its overlying GCs and forms a structure called the germinal disc region (GDR). GCs cannot be separated from it (Perry et al. 1978, Tischkau \& Bahr 1996, Malewska \& Olszanska 1999). Estrogen production by hierarchical follicles declines from $\mathrm{F} 6$ to $\mathrm{F} 1$, while progesterone production increases (Huang \& Nalbandov 1979). The GCs from the largest follicles produce large amounts of progesterone. In contrast to mammalian GCs, chicken GCs produce no estrogen, which is synthesized only by theca cells (Huang \& Nalbandov 1979, Marrone \& Hertelendy 1983).

Few studies have been undertaken on BMP expression and roles in hen ovaries. Onagbesan et al. (2003) have shown that BMP4 and BMP7 increase basal and insulin-like growth factor-I (IGF-I)- and gonadotropin-induced progesterone production in hen GCs (Onagbesan et al. 2003). Moreover, they have demonstrated that BMP4 inhibits FSH-stimulated GC proliferation (Onagbesan et al. 2003). Another recent study indicated that GDF9 is expressed in both hen oocytes and GCs, where it exerts a mitogenic effect (Johnson et al. 2005). However, most of the presumptive ovarian roles of BMPs remain unexplored in birds.

The aim of the present study was first to determine the temporal and spatial dynamics of the Bmp15 gene expression and to confirm those of Gdf9 in the hen ovary and early embryogenesis, and then to investigate in vitro the effects of BMP15 on GC proliferation and steroidogenesis.

\section{Materials and Methods}

\section{Animals}

Laying breed hens, aged 60-70 weeks (ISA Brown, egg layer type, Institut de Selection Animale, Saint Brieuc, France), were housed individually in laying batteries with free access to feed and water and were exposed to a $15 \mathrm{~h}$ light: $9 \mathrm{~h}$ darkness photoperiod, with lights-on at $2000 \mathrm{~h}$. Individual laying patterns were monitored daily. For in situ hybridization, these hens and younger ones aged 10 weeks were used to provide mature and immature ovaries, in order to study follicles of each stage. Hens used to provide fertilized eggs were inseminated once a week.

\section{Hormones and reagents}

Purified ovine FSH-20 (oFSH; lot no. AFP-7028D, $4453 \mathrm{IU} / \mathrm{mg}, \mathrm{FSH}$ activity $=175$ times activity of oFSH-S1) and purified ovine luteinizing hormone ( $\mathrm{LH}$; lot 26; a gift from NIDDK, National Hormone Pituitary Program, Bethesda, MD, USA) and human recombinant IGF-I (Sigma) were used for culture treatment. Dulbecco's modified Eagle's medium (DMEM), penicillin, and streptomycin were purchased from Invitrogen, and thymidine methyl- $\mathrm{H}^{3}$ from Perkin-Elmer Life and Technological Sciences (Boston, MA, USA). Human recombinant BMP15 was prepared as previously described (Di Pasquale et al. 2004). Human recombinant and chicken proteins showed $44 \%$ identity, but the two proteins are $72 \cdot 8 \%$ identical and $79.8 \%$ homologous in the C-terminal mature peptide region (Fig. 1). Human recombinant $\mathrm{BMP} 4$ was purchased from R\&D (R\&D Systems, Oxon, UK); human and chicken BMP4 are $84 \%$ identical.

\section{Antibodies}

Rabbit polyclonal antibodies to phospho-Smad1 and Smad1 were purchased from Upstate Biotechnology Inc. (Lake Placid, NY, USA). Rabbit polyclonal antibodies against P450scc and StAR were generously provided by Dr Dale Buchanan Hales (University of Illinois, Chicago, IL, USA) and antibodies against $3 \beta-H S D$ by Dr Van Luu-The (CHUL Research Center and Laval University, Canada). The monoclonal antibody to Vinculin was obtained from Sigma. All antibodies were used at 1: 1000 dilution in western blot analysis.

\section{RNA isolation and RT-PCR}

Hens aged 60 weeks were used. Total RNA was extracted from different tissues (ovary, spleen, intestine, gizzard, liver, heart, skin, brain, pectoralis muscle, and lung) and GDRs (Malewska \& Olszanska 1999) from different preovulatory follicles (F1-F6) as previously described, just ovulated oocytes and early embryos at $6 \cdot 5,12,24,36$, and $48 \mathrm{~h}$ post-ovulation. For the last two stages, eggs were incubated at $37 \cdot 8^{\circ} \mathrm{C}$ for 12 and $24 \mathrm{~h}$ respectively. During follicular maturation, the GDR used for these studies consisted of not only the germinal disc but also the overlying layer 


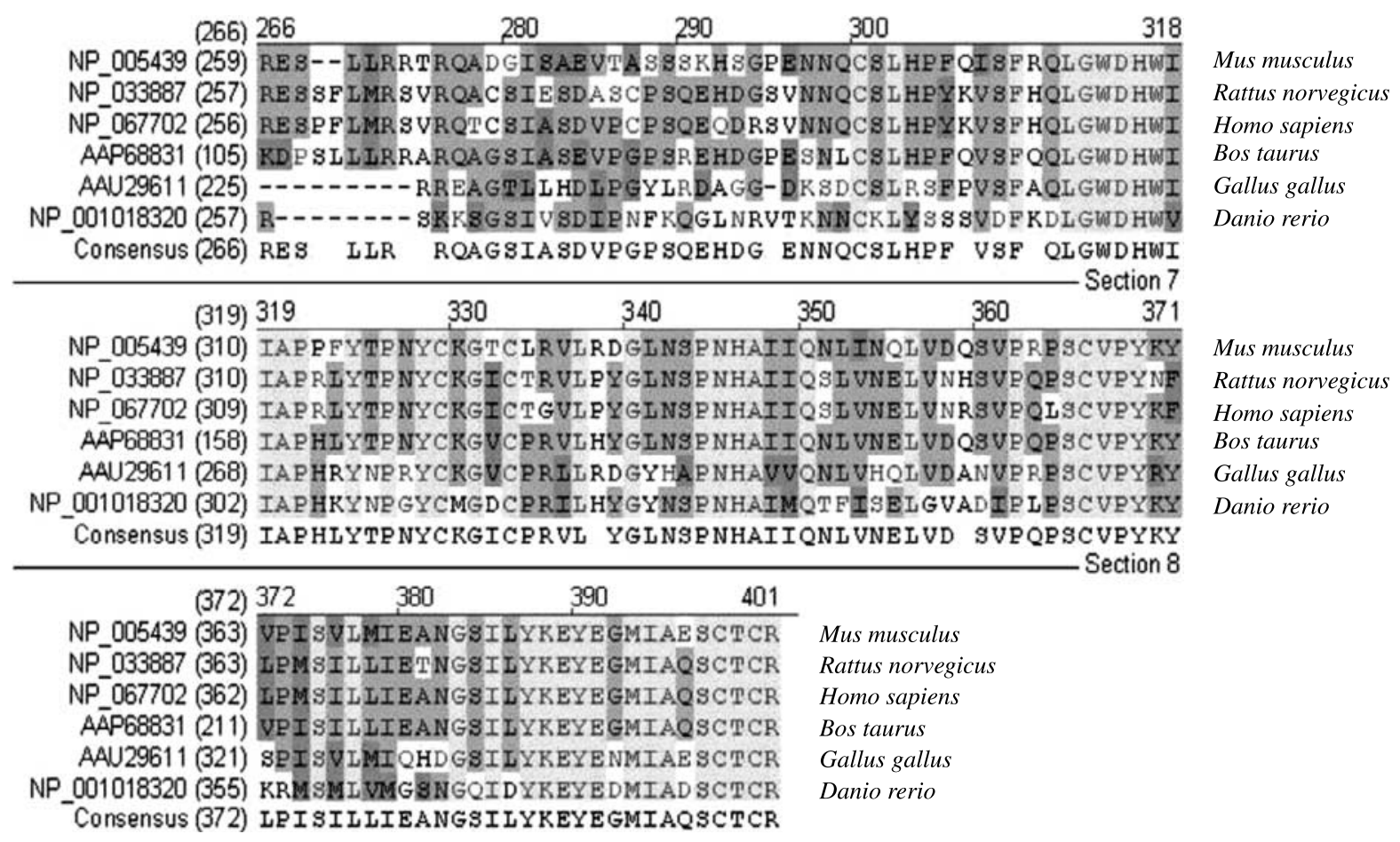

Figure 1 Aligned amino acid sequence. Data for chicken BMP15 compared with several species in the biologically C-terminal region. The lightgrey shading indicates areas of identity and the dark-grey one indicates areas of similarity between the six species shown.

of GCs, because it is impossible to separate the germinal disc from its overlying GCs (Tischkau \& Bahr 1996). However, the number of GCs could not be measured. Total RNA was extracted using TRI reagent according to manufacturer's procedure (Euromedex, Mundolsheim, France). RNA was quantified by measuring the absorbance at $260 \mathrm{~nm}$. Samples were stored at $-80^{\circ} \mathrm{C}$ until use. RT PCR was performed to test the expression of Bmp15 and Gdf9 genes in different tissues and at different stages of follicular maturation and embryo development. Specific sets of primer pairs designed to amplify parts of Bmp 15 and Gdf9 genes are shown in Table 1. PCR amplification without cDNA was performed in parallel as negative control. RT-PCR disposables were purchased from Sigma, except for Moloney murine leukemia virus reverse transcriptase and RNase inhibitor (RNasin) which were purchased from Promega. Real-time PCR disposables were purchased from Eurogentec (qPCR Mastermix Plus for Sybr Green I, Eurogentec, Angers, France). Ef1- $\alpha$ was used as reporter gene, its expression being similar in GCs and in GDR (data not shown). GCs without germinal disc and GCs localized in the vicinity of the germinal disc were studied as control for each follicle stage used.

In situ hybridization

Female chickens were killed at different stages of sexual development. Two types of tissues were used: mature ovaries

Table 1 Oligonucleotide primer sequences

Sequence

\section{Primer}

bmp15 forward 1 bmp15 reverse 1 gdf 9 forward 1 gdf9 reverse 1 bmp 15 forward 2 bmp 15 reverse 2 gdf9 forward 2 gdf9 reverse 2 ef $1-\alpha$ forward ef $1-\alpha$ reverse

\begin{tabular}{|c|c|c|}
\hline Sequence & Accession number & Product size $(b p)$ \\
\hline GGG GGA TTT GGG TTT TAG CC & AY725199 & 142 \\
\hline GGT AAA GCA GAA AGA GGT CCC G & & \\
\hline TGA TGT GAC TTC TTT TCT GCG GC & AY 672110 & 105 \\
\hline TTA GTG TTA TGT TGC GGG TTA CCC & & \\
\hline TGG GGG ATT TGG GTT TTA GC & AY725199 & 727 \\
\hline AAA TAG GGG GTG ATG TCC GC & & \\
\hline GGT ACG TGG AGG ATC TGT GTT TGT T & AY672110 & 757 \\
\hline CCT GTT TAG TGT TAT GTT GCG GG & & \\
\hline AGC AGA CTT TGT GAC CTT GCC & NM 204157 & 83 \\
\hline TGA CAT GAG ACA GAC GGT TGC & & \\
\hline
\end{tabular}


containing follicles of different sizes $(50 \mu \mathrm{m}-7 \mathrm{~mm})$ from 60 -week-old hens, most follicles being larger than $300 \mu \mathrm{m}$, and immature ovaries containing a majority of small follicles $(25-500 \mu \mathrm{m})$ from 10-week-old hens, most follicles being smaller than $100 \mu \mathrm{m}$. Mature and immature ovaries were then collected and embedded in Tissue-Tek (Sakura Finetek Europe BV, Zoeterwoude, The Netherlands). Frozen ovaries were serially sectioned with a cryostat (thickness of $10 \mu \mathrm{m}$ ) to perform in situ hybridization experiments using ${ }^{35}$ S-labeled chicken Bmp15 and Gdf9 cRNA. The bmp15 and gdf9 antisense and sense constructs used for in situ hybridization were generated by inserting fragments of chicken Bmp15 or Gdf9 cDNA (727 and 757 bp respectively) into the pGEM-T vector (Promega), and selecting a clone with the appropriate antisense or sense orientation. The Bmp15 and Gdf9 cDNA fragments were generated by RT-PCR from chicken ovary mRNA using forward and reverse primers (Table 1). The in situ hybridization was performed as previously described (Pierre et al. 2005). Hybridization specificity was assessed by comparing signals obtained with the cRNA antisense probe and the corresponding $\mathrm{cRNA}$ sense probe.

\section{Isolation and culture of GCs}

Hens were killed $12 \mathrm{~h}$ before the next oviposition, and the follicles were immediately removed and placed in ice-cold sterile $1 \% \mathrm{NaCl}$ saline solution for immediate use. GCs from $\mathrm{F} 1, \mathrm{~F} 2$, and mixed F3 and F4 (F3/4) follicles were dispersed in $0 \cdot 3 \%$ collagenase type A (Roche Diagnostic) in F12 medium containing 5\% FBS. Cells were recovered by centrifugation, washed with fresh medium, and counted in a hemocytometer. The culture medium was DMEM supplemented with $100 \mathrm{U} / \mathrm{ml}$ penicillin, $100 \mathrm{mg} / \mathrm{l}$ streptomycin, $3 \mathrm{mmol} / 1$ L-glutamine, and 5\% FBS. The cells were initially cultured for $24 \mathrm{~h}$ in serum-supplemented medium (5\%) with no treatment and incubated in fresh culture serum-free medium with or without test reagents for the appropriate time. All cultures were performed under a water-saturated atmosphere of 95\% air $/ 5 \% \mathrm{CO}_{2}$ at $37^{\circ} \mathrm{C}$. Seven independent replicate cultures were carried out.

\section{Western blotting}

GCs were solubilized and centrifuged as previously described (Tosca et al. 2005). Cell extracts were then submitted to electrophoresis on 10\% (w/v) SDS-polyacrylamide gel under reducing conditions and electrotransferred as previously described (Tosca et al. 2005). The membranes were then incubated overnight at $4{ }^{\circ} \mathrm{C}$ with appropriate antibodies (final dilution 1:1000) in Tris-buffered saline (TBS, $2 \mathrm{mM}$ Tris- $\mathrm{HCl}$ ( $\mathrm{pH}$ 8), $15 \mathrm{mM} \mathrm{NaCl}(\mathrm{pH} 7 \cdot 6)$ ) containing $0 \cdot 1 \%$ Tween 20 and $5 \%$ non-fat dry milk powder (NFDMP). After washing in TBS-Tween $20(0 \cdot 1 \%)$, nitrocellulose membranes were incubated for $2 \mathrm{~h}$ at room temperature with a horseradish peroxidase-conjugated anti-rabbit or anti-mouse IgG (final dilution 1:10 000; Diagnostic Pasteur, Marnes-la-Coquette,
France) in TBS-Tween $20(0 \cdot 1 \%)$ NFDMP (5\%). After washing in TBS-Tween $20(0 \cdot 1 \%)$, the signal was detected by enhanced chemiluminescence (Amersham Pharmacia Biotech). The films were analyzed and signals quantified with the Scion Image Beta software 4.0.2 (Fuji PhotoFilm, Edison, NJ, USA).

\section{Progesterone RIA}

The concentration of progesterone in the GC culture medium was measured after $32 \mathrm{~h}$ of culture by an RIA protocol as previously described (Tosca et al. 2006), adapted to measure steroids in cell culture media (Tosca et al. 2006). The limit of detection of progesterone was $12 \mathrm{pg} /$ tube $(60 \mathrm{pg} /$ well) and the intra- and inter-assay coefficients of variation were $<10$ and $11 \%$ respectively. Results were expressed as theamount of steroids secreted per 300000 cells over $32 \mathrm{~h}$ (number of cells/well).

\section{Thymidine incorporation into GCs}

GCs were seeded in 24 -well dishes $\left(2 \times 10^{5}\right.$ viable cells $/ 500 \mu \mathrm{l})$. After $24 \mathrm{~h}$, cells were serum starved overnight, and $\left[{ }^{3} \mathrm{H}\right]$ thymidine $(1.5 \mu \mathrm{Ci} / \mathrm{ml})$ was added in the absence or presence of BMP15 (50 or $200 \mathrm{ng} / \mathrm{ml}$ ), BMP4 (5 or $50 \mathrm{ng} / \mathrm{ml})$, IGF-I $\left(10^{-8} \mathrm{M}\right)$, LH $\left(10^{-8} \mathrm{M}\right)$, or FSH $\left(10^{-8} \mathrm{M}\right)$. After $24 \mathrm{~h}$, excess $\left[{ }^{3} \mathrm{H}\right]$ thymidine was removed by washing twice with PBS; cells were then fixed with ice-cold trichloroacetic acid (50\%) and lysed by $\mathrm{NaOH}$ $(0.5 \mathrm{~N})$. The radioactivity in the cells was determined after resuspension by scintillation counting in a $\beta$-photomultiplier. Seven independent replicate experiments were carried out.

\section{Statistical analysis}

All experimental data are presented as means \pm s.E.M. Oneway ANOVA was used to test differences. If ANOVA revealed significant effects, the means were compared by Fisher's test, with $P<0.05$ considered significant. Different letters indicate significant differences.

\section{Results}

Expression of Bmp15 and Gdf9 mRNA in hen ovary and other tissues

RT-PCR analysis showed that Bmp15 and Gdf9 were preferentially expressed in the hen ovary. However, Bmp15 mRNAs were also present in the brain, but at a low level (Fig. 2). This latter expression was confirmed by real-time PCR (data not shown). In situ hybridization on ovarian sections (Fig. 3) revealed that Bmp 15 mRNA was found in small oocytes from follicles of 50-100 $\mu \mathrm{m}$ from both immature (Fig. 3A) and mature ovaries, and in larger oocytes from follicles of $500 \mu \mathrm{m}-$ $6 \mathrm{~mm}$ from mature ovaries (Fig. 3C). Gdf9 mRNA was also 
Bmp15
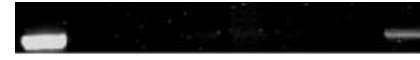

Gdf9

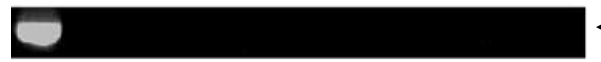

757

Efl alpha

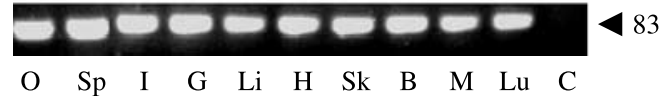

Figure 2 RT-PCR analysis of Bmp15 and Gdf9 genes in hen tissues. Total RNA was isolated from whole ovary $(\mathrm{O})$, spleen (Sp), intestine $(\mathrm{I})$, gizzard $(\mathrm{G})$, liver $(\mathrm{Li})$, heart $(\mathrm{H})$, skin $(\mathrm{Sk})$, brain $(B)$, muscle $(M)$, and lung (Lu) tissues, and RT-PCR was performed as described in Materials and Methods. Ethidium bromide staining of the gel is shown for Bmp15, Gdf9, and Ef1- $\alpha$. Ef1- $\alpha$ was chosen as an ubiquitous gene. (C) corresponds to the negative control (water).

observed in small oocytes from follicles of 50-100 $\mu \mathrm{m}$ from immature ovaries (Fig. 3B), and a signal was found in oocytes from all follicles of $50 \mu \mathrm{m}-6 \mathrm{~mm}$ from mature ovaries (Fig. 3D). No significant expression was detected in somatic cells.

A. Bmp15: Immature ovary
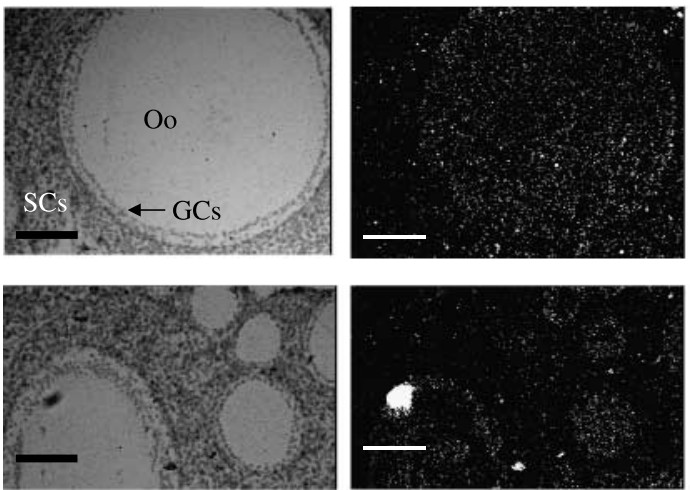

C. Bmp15 : Mature ovary
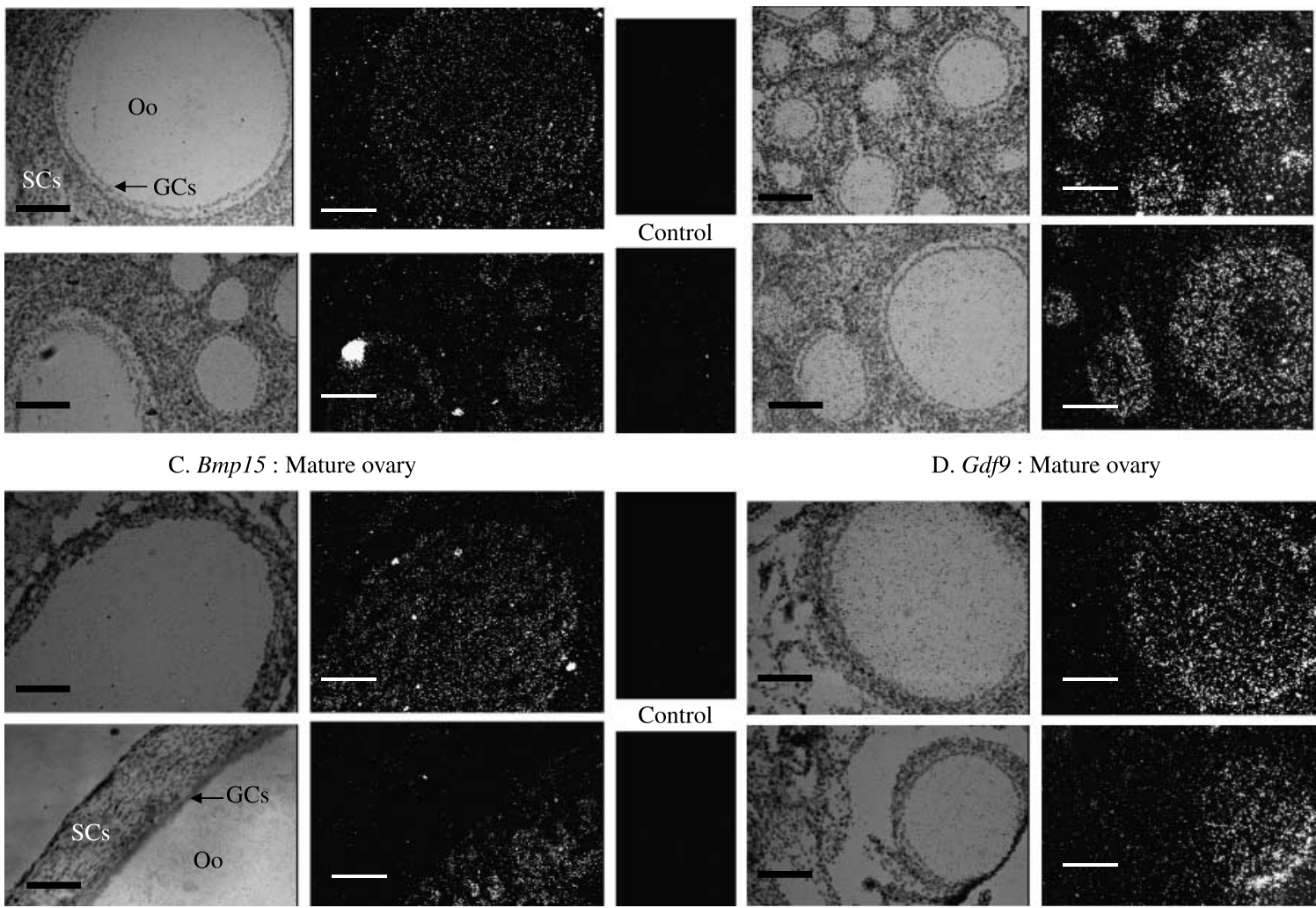

D. Gdf9 : Mature ovary
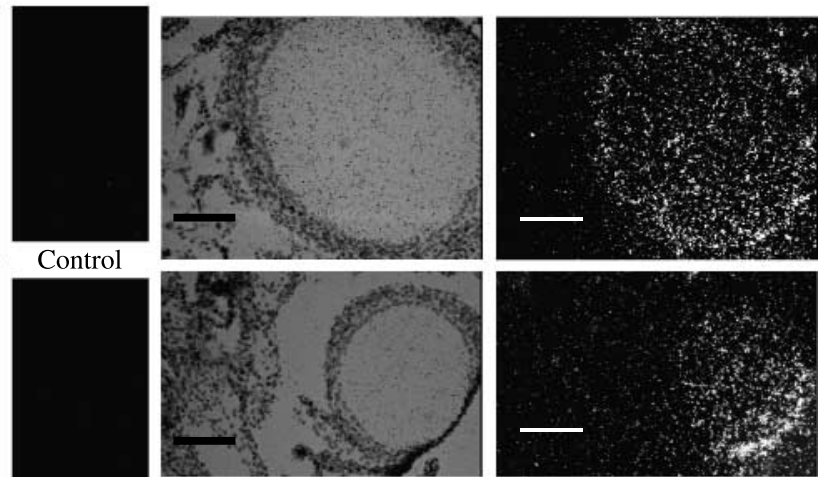

Figure 3 Localization of Bmp15 and gdf9 mRNA in the hen ovary. Localization of Bmp15 (A and C) and Gdf9 (B and D) by in situ hybridization in immature ovaries (A and $B$ ) and in mature ovaries (C and D). Bright fields are on the left and dark fields are on the right. The control sections were hybridized with the Bmp15 or Gdf9 sense probes. Oocytes (Oo), granulosa cells (GCs), and somatic cells (SCs) are indicated. Scale bar $=100 \mu \mathrm{m}$. 
A. $B m p 15$

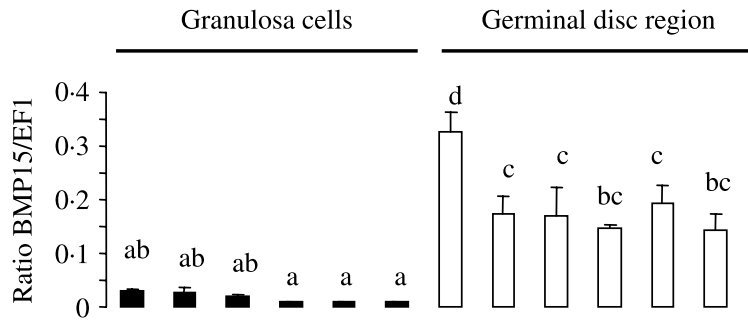

$\begin{array}{llllllllllllllllll} & \text { F6 } & \text { F5 } & \text { F4 } & \text { F3 } & \text { F2 } & \text { F1 } & \text { F6 } & \text { F5 } & \text { F4 } & \text { F3 } & \text { F2 } & \text { F1 }\end{array}$
B. $G d f 9$

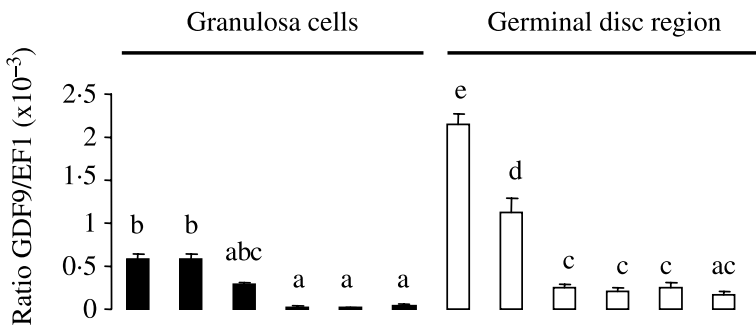

$\begin{array}{lllllllllllllllllll}\text { F6 } & \text { F5 } & \text { F4 } & \text { F3 } & \text { F2 } & \text { F1 } & \text { F6 } & \text { F5 } & \text { F4 } & \text { F3 } & \text { F2 } & \text { F1 }\end{array}$
C. Bmp15

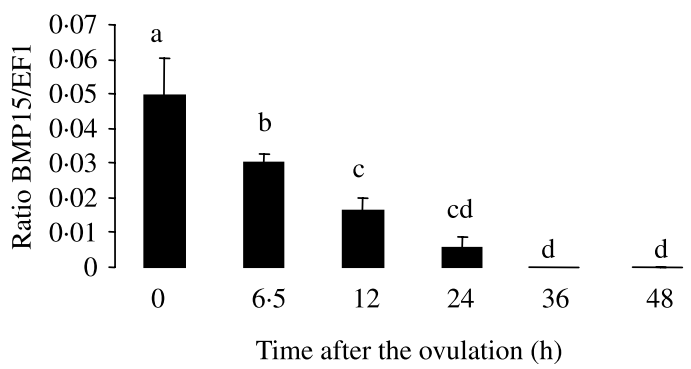

D. $G d f 9$

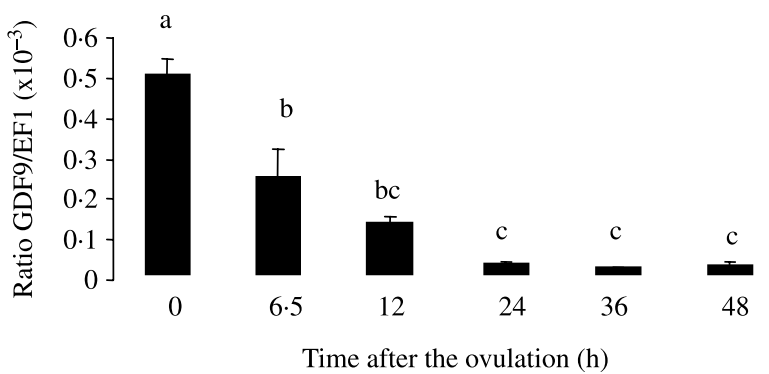

Figure 4 Expression of Bmp15 and Gdf9 genes during follicular maturation and early embryo development. Real-time RT-PCR analysis was performed on GCs and germinal disc regions of the six largest follicles of the hen ovary. Follicles are designated as F6-F1, F1 being the largest follicle taken $24 \mathrm{~h}$ before ovulation. A and B show the expression in GCs and germinal disc regions of Bmp 15 and Gdf9 respectively. C and D show the expression during early embryo development, at the moment of ovulation and 6.5, 12, 24, 36, and $48 \mathrm{~h}$ after ovulation of Bmp15 and $G d f 9$ respectively. Expression of Bmp15 and $G d f 9$ was quantified in relation to the ubiquitous gene Ef1- $\alpha$. Results represent means \pm s.E.M. The same letters indicate that difference was not significant. Different letters indicate that difference was significant $(P<0 \cdot 05)$.

have a biological function in GCs in both the hen (Onagbesan et al. 2003) and in different mammals (Pierre et al. 2004, Fabre et al. 2006). Western blot analysis revealed that both peptides significantly increased phosphorylation of Smad1 in GCs from F1 and F3/4 (Fig. 5). However, there was no significant effect of BMP15 on the state of MAPK p38 phosphorylation, a member of the MAPK signaling pathway (data not shown).

\section{Effects of BMP15 on GC steroidogenesis}

We next studied the effects of BMP15 on GC steroidogenesis at different stages of follicular maturation (F3/4, F2, and F1). Avian GCs produce no estradiol, so we investigated only the effect of BMP15 on the progesterone level. Surprisingly, IGF-I had no stimulatory effect on progesterone secretion for each stage considered and even a 1.7-fold inhibitory effect on F1 GCs (Fig. 6C). As expected, LH treatment caused an increase in progesterone production for each stage tested (F3/ 4, F2, and F1 GCs; Fig. 6). FSH treatment increased progesterone production in GCs from F3/4 and F2 follicles, but no significant effect was observed in F1 GCs. LH treatment induced 3.5- $(P<0 \cdot 0001), 3 \cdot 9-(P<0 \cdot 0001)$, and $1 \cdot 5$-fold $(P<0 \cdot 0001)$ increases in progesterone secretion on F3/4, F2, and F1 GCs respectively (Fig. 6A-C). FSH treatment induced $1 \cdot 6-(P<0 \cdot 05)$ and $1 \cdot 9$-fold $(P<0 \cdot 0001)$ increases in progesterone secretion on F3/4 and F2 GCs respectively (Fig. 6A and $\mathrm{B}$ ).

BMP15 $(200 \mathrm{ng} / \mathrm{ml})$ induced a $1 \cdot 3$-fold $(P<0 \cdot 05)$ decrease in basal progesterone production on F1 GCs (Fig. 6C). No effect on basal progesterone secretion was observed at the other stages, whatever the BMP15 concentration. On the other hand, BMP15 showed a strong inhibitory effect on LH- and FSH-induced progesterone secretion for the different stages considered (Fig. 6). In F3/4 GCs, LH-induced progesterone production decreased $4 \cdot 6$-fold $(P<0 \cdot 0001)$, and FSH-induced progesterone production decreased $2 \cdot 9$-fold $(P<0 \cdot 001)$ under BMP15 treatment. In F2 GCs, LH- and FSH-induced progesterone production decreased $2 \cdot 8-(P<0 \cdot 0001)$ and $2 \cdot 4$-fold $(P<0 \cdot 0001)$ respectively. In F1 GCs, only the inhibitory effect on $\mathrm{LH}$-induced progesterone secretion was significant, decreasing twofold $(P<0 \cdot 0001)$. Similar overall effects were observed with BMP4 (Fig. 6).

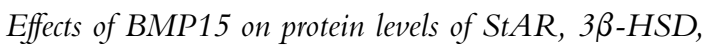
and P450scc

BMP15 did not have any effect on the expression of the $3 \beta$ HSD and P450scc steroidogenesis enzymes as assessed by immunoblot analysis, whatever the treatment or stages 


\section{A. F3/4}

Blot: Phospho-Smad1

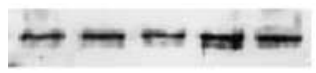

Blot: Smad1

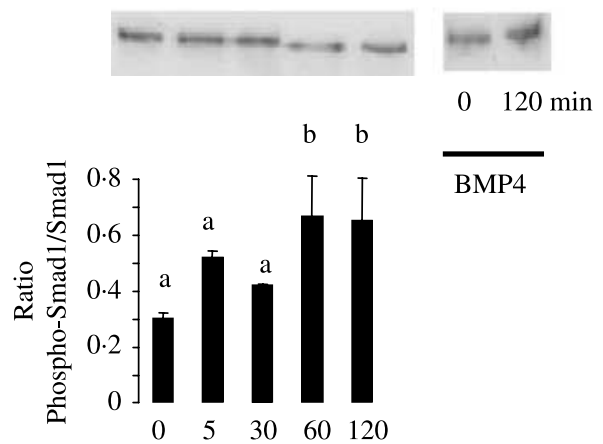

Time of BMP15 stimulation (min)
B. F1

Blot: Phospho-Smad1

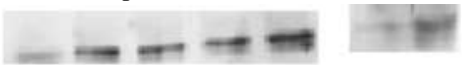

Blot: Smad1
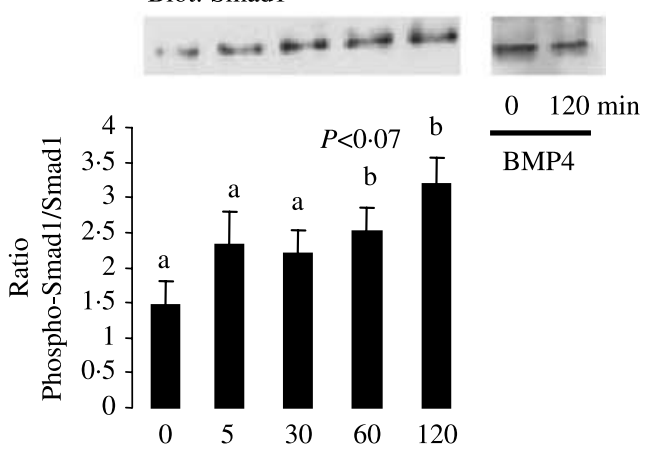

Time of BMP15 stimulation (min)

Figure 5 Effects of BMP15 on levels of Smad1 phosphorylation. GCs were cultured in the presence of BMP15 $(50 \mathrm{ng} / \mathrm{ml})$ or BMP4 $(5 \mathrm{ng} / \mathrm{ml})$ for $0,5,30,60$, and $120 \mathrm{~min}$. Western blot analysis was then performed, and membranes were probed with an antibody against phospho-Smad and then reprobed with an antibody against Smad1 antibody. Data are represented as the phospho-Smad1/Smad1 ratio in F3/4 GCs (A) and in F1 GCs (B). Results represent means \pm S.E.M. The same letters indicate that difference was not significant. Different letters indicate that difference was significant $(P<0 \cdot 05)$.

studied (data not shown). Expression of StAR increased when GCs from F3/4 to F1 were treated by LH, and when GCs from F3/4 and F2 were treated by FSH (Fig. 7). Combined treatment with LH or FSH and BMP15 $(50 \mathrm{ng} / \mathrm{ml})$ had a significant inhibitory effect on the expression of StAR $(P<0 \cdot 0001$ and $P<0 \cdot 01$ respectively) in F3/4 and F2 GCs (Fig. 7A and B). In F1 GCs, only combined treatment with $\mathrm{LH}$ and BMP15 resulted in a significant decrease in the protein level of StAR $(P<0 \cdot 05$; Fig. 7C). Similar results were found after BMP4 treatment, but the effect was slighter.

\section{Effects of BMP15 on GC proliferation}

IGF-I had the greatest stimulatory effect on GCs, the thymidine incorporation level being increased 2.8-, 2·7-, and 4.1-fold in F3/4, F2, and F1 GCs respectively (Fig. 8). The stimulatory effect of LH on proliferation was only significant in F1 GCs (1.9-fold). FSH also had a significant stimulatory effect in F3/4 and F1 GCs (1.7- and 1.6-fold respectively). No significant effect of BMP15 alone was observed. In F3/4 GCs, combined treatment with FSH and BMP15 $(50 \mathrm{ng} / \mathrm{ml})$ resulted in a significant decrease in thymidine incorporation $(P<0 \cdot 001$; Fig. 8A). No other significant effect was observed with combined BMP15 and IGF-I or gonadotropin treatment. Only significant stimulatory effect of BMP4 on proliferation induced by IGF-I in F2 GCs was observed. No effect of BMP15 $(200 \mathrm{ng} / \mathrm{ml}$ ) was observed on GC viability when evaluated with Trypan blue staining (data not shown).

\section{Discussion}

The regulation of the expression and function of chicken genes involved in the endocrine-dependent maturation of the oocyte has some consequences on the development of the early embryo. Among these factors, the genes of the TGF- $\beta$ family, including $G d f 9$ and $B m p 15$, may be particularly important. The Gdf9 gene has already been shown to be an ovary-specific gene and to exert positive effects on GC proliferation in many species (mice, rat, human, and hen; Juengel et al. 2004, Johnson et al. 2005). In the present study, we demonstrated that Bmp15 was expressed in the germinal disc and in the early embryo in the hen. Moreover, we showed a strong inhibitory effect of human BMP15 on gonadotropin-induced progesterone production of hen GCs. This inhibitory effect was associated with a decrease in StAR protein level.

As in mammals (Fitzpatrick et al. 1998, Aaltonen et al. 1999, Bodensteiner et al. 1999, Jaatinen et al. 1999, Eckery et al. 2002), we confirmed in this study that Gdf9 has specific ovarian expression in the hen (Johnson et al. 2005). The Bmp 15 gene has also been reported to be oocyte specific in most species (Juengel et al. 2004), and for the first time to our knowledge, we found that it was mainly expressed in the hen ovary, with weak expression also occurring in the brain. Our real-time RT-PCR data showed a slight expression in the pituitary gland (data not shown). This latter result is concordant with studies on rats which showed that the Bmp 15 gene was slightly expressed in the pituitary gland (Otsuka \& Shimasaki 2002). 
A. F $3 / 4$

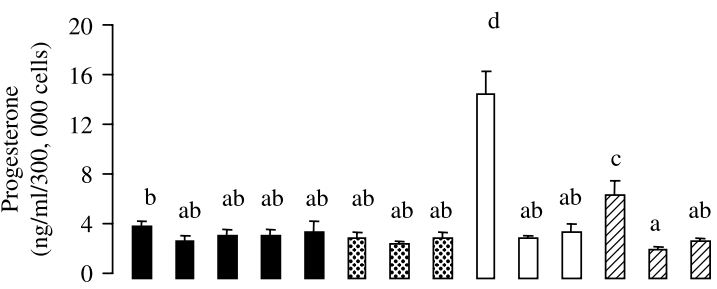

B. F2

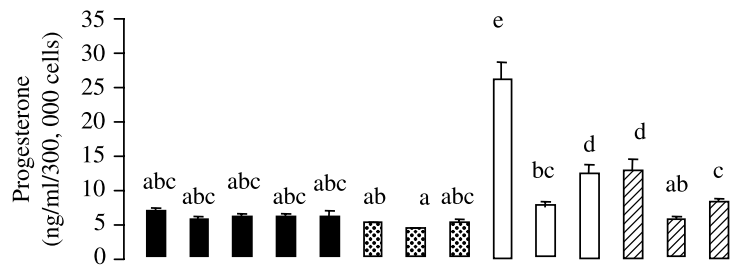

\section{F1}

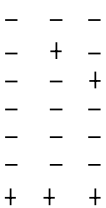

$\begin{array}{lllllllllllllll}\text { BMP15, 200 } & - & + & - & - & - & - & - & - & - & - & - & - & - & - \\ \text { BMP15, 50 } & - & - & + & - & - & - & + & - & - & + & - & - & + & - \\ \text { BMP4, 5 } & - & - & - & + & - & - & - & + & - & - & + & - & - & + \\ \text { BMP4, 50 } & - & - & - & - & + & - & - & - & - & - & - & - & - & - \\ \text { IGF-1 } & - & - & - & - & - & + & + & + & - & - & - & - & - & - \\ \text { LH } & - & - & - & - & - & - & - & - & + & + & + & - & - & - \\ \text { FSH } & - & - & - & - & - & - & - & - & - & - & - & + & +\end{array}$

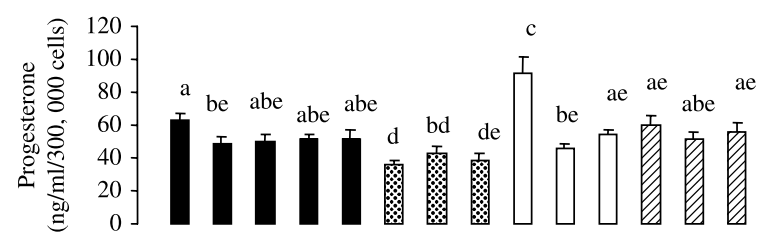

\begin{tabular}{|c|c|c|c|c|c|c|c|c|c|c|c|c|c|}
\hline BMP15, 200 & - & t & - & - & - & - & - & - & - & - & - & - & - \\
\hline BMP15, 50 & - & - & + & - & - & - & + & - & - & + & - & - & + \\
\hline BMP 4,5 & - & - & - & + & - & 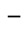 & - & + & - & - & $t$ & - & - \\
\hline BMP4, 50 & - & - & - & - & t & - & - & - & - & - & - & - & - \\
\hline IGF-1 & - & - & - & - & - & t & + & + & - & - & - & - & - \\
\hline LH & - & - & - & - & - & - & - & - & t & $t$ & $t$ & - & - \\
\hline FSH ZD & 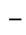 & - & - & - & - & - & - & - & - & - & - & $t$ & + \\
\hline
\end{tabular}

Figure 6 Effects of BMP15 on progesterone secretion by cultured hen GCs. GCs (300 000 viable cells) were cultured in serum-free medium as described in Materials and Methods in the presence or absence of IGF-I $\left(10^{-8} \mathrm{M}\right)$, LH $\left(10^{-8} \mathrm{M}\right)$, or FSH $\left(10^{-8} \mathrm{M}\right)$ with the combination of BMP15 (50 or $200 \mathrm{ng} / \mathrm{ml}$ ) or BMP4 (5 or $50 \mathrm{ng} / \mathrm{ml}$ ). Progesterone secretion was measured in GCs at different stages of follicular maturation (F3/4, F2, and F1: A, B, and C respectively). After $32 \mathrm{~h}$ of culture, the progesterone levels in the medium were measured by RIA. Each combination of treatments was tested in quadruplicate in seven independent experiments. Results represent ng/ml of progesterone secretion by 300000 GCs after $32 \mathrm{~h}$ of culture in vitro. Data are shown as means \pm s.E.M. Different letters indicate that difference was significant $(P<0 \cdot 05)$. Seven independent experiments were performed in triplicate.

We succeeded in using in situ hybridization on hen ovaries and specifically localized Bmp 15 and Gdf9 mRNA in oocytes. This localization was close to that previously found in mammals (Aaltonen et al. 1999, Bodensteiner et al. 2000). The Gdf9 and Bmp 15 genes were expressed in all hen follicles studied $(50 \mu \mathrm{m}-6 \mathrm{~mm})$. It was surprising to observe almost wide-spread localization of Gdf9 mRNA throughout the oocyte, while previous immunocytochemistry studies (Johnson et al. 2005) localized GDF9 protein under the vitelline membrane adjacent to the granulosa layer. However, these techniques are different and do not localize the same molecules, mRNA or protein. Moreover, in our in situ hybridization experiments, any signal was observed with sense probes, strongly suggesting that the hybridizations are specific. However, in small oocytes $(<1 \mathrm{~mm})$, it is already known that the germinal disc is localized in the center of the oocyte (Sauveur 1988). Then, the germinal disc moved to the surface of the oocyte, where it stayed until the end of the follicle growth. This could explain why we found a central localization of mRNA in the oocyte.
In situ hybridization did not detect any significant signals of Bmp15 and Gdf9 in hen GCs. However, we also observed a slight expression in GCs by real-time RT-PCR, in accordance with previous studies in primate (Duffy 2003) and in the hen (Johnson et al. 2005). However, it is possible that there is a contamination of GCs dissected from perivitelline membrane by the so-called 'extra-embryonic' RNA, i.e., by mRNA containing oocyte cytoplasm, as previously described by Malewska \& Olszanska (1999). Moreover, the different sensitivity of these two techniques could explain our results.

As shown in mammals, both could be involved in the differentiation of growing follicles, rather than in early embryo development (Juengel et al. 2004, Li et al. 2007, Pennetier et al. 2004, Su et al. 2004). Indeed, as shown in the bovine model (Pennetier et al. 2004), the expression of both of these genes decreases after ovulation, even after embryonic genome activation. Our data suggest that the levels of Gdf9 and Bmp 15 mRNA in germinal disc start to decrease after ovulation but they are still present till oviposition, $24 \mathrm{~h}$ postovulation, and disappear in the case of Bmp 15 after embryonic 

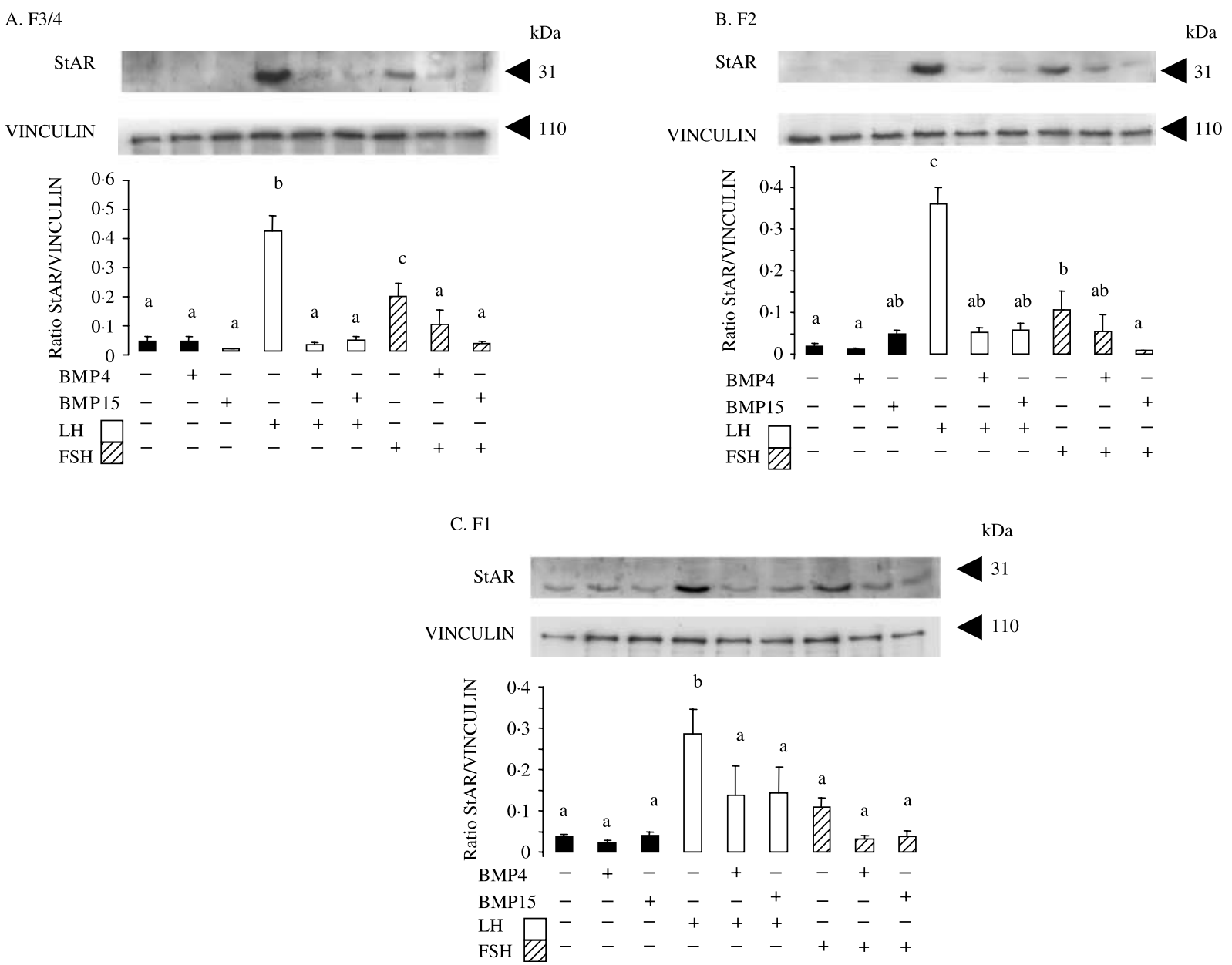

Figure 7 Effects of BMP15 on StAR protein level. GCs (300 000 viable cells) were cultured in serum-free medium as described in Materials and Methods in the presence or absence of IGF-I $\left(10^{-8} \mathrm{M}\right), \mathrm{LH}\left(10^{-8} \mathrm{M}\right)$, or FSH $\left(10^{-8} \mathrm{M}\right)$ with the combination of BMP15 (50 or $\left.200 \mathrm{ng} / \mathrm{ml}\right)$ or BMP4 ( 5 or $50 \mathrm{ng} / \mathrm{ml}$ ) for $32 \mathrm{~h}$. Total cellular proteins were then extracted and subjected to western blotting as described in Materials and Methods. All extracts were probed with anti-StAR antibody and then reprobed with anti-Vinculin antibody. The StAR protein level was measured in GCs from F3/4, F2, and F1 preovulatory follicles (A, B, and C respectively). Data presented are representative of four independent experiments. Data are shown as means \pm S.E.M.

genome activation which occurs soon after oviposition (Zagris et al. 1998). The chicken embryonic genome reactivation occurs when the embryo contains $30000-$ 50000 cells. The relevance of this study is reinforced by the fact that proteins and mRNA accumulated during chicken oocyte maturation are essential not only for fertilization and first cleavage but also for supporting such a high number of embryonic cell divisions. For comparison, in the cattle model, the embryonic genome is activated at the eight-cell stage (Meirelles et al. 2004), and in the murine model, it occurs at the two-cell stage (Eric et al. 1998).

Since it is difficult to realize GC culture from follicles smaller than F4, and even if BMP15 expression is higher in small than in large follicles, we studied BMP15 effects on GCs from F3/4 to F1 stage. The increase in Smad1 phosphorylation after BMP15 treatment showed for the first time that, as in mammals (Moore et al. 2003), BMP15 may activate the Smad 1/5/8 pathway in chicken GCs. BMP4 exhibited the same increase in level of Smad1 phosphorylation, confirming results obtained in other vertebrate models (Balemans \& Van Hul 2002). Other studies have shown that the MAP kinase pathway (ERK, p38) is involved in the intracellular transduction of BMP signals (Moore et al. 2003, Su et al. 2004). However, no significant effect of BMP15 on p38 phosphorylation was observed in the present study (data not shown). It would be interesting to see whether BMP15 activates the p38 signaling pathway in mammals.

As previously observed with perfused rabbit ovaries (Yoshimura et al. 1996), in our study, IGF-I alone showed no effect on progesterone secretion by GCs, whatever the follicular stage. Onagbesan et al. (2003) discussed the lack of effect of BMP4 and IGF-I alone on hen GCs, and hypothesized that 
A. F3/4

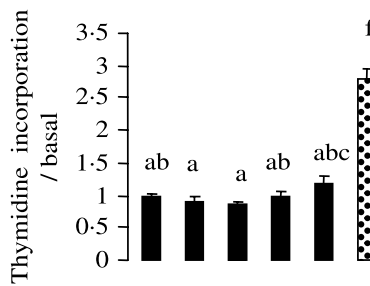

B. F2

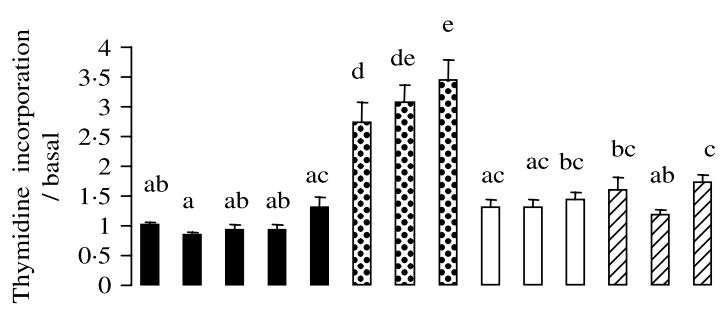

\begin{tabular}{|c|c|c|c|c|c|c|c|c|c|c|c|c|c|c|c|c|c|c|c|c|c|c|c|c|c|c|c|c|c|}
\hline $3 \mathrm{MP} 15,200$ & - & $t$ & - & - & - & - & - & - & - & - & - & - & - & - & BMP15, 200 & - & t & - & - & - & - & - & . & & & & - & - & - \\
\hline BMP15, 50 & - & - & + & - & - & - & + & - & - & + & - & - & + & - & BMP15, 50 & . & 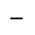 & + & - & 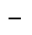 & - & + & - & & & & . & - & + \\
\hline BMP4, 5 & - & - & - & + & - & - & - & $t$ & - & - & + & - & - & + & BMP4, 5 & 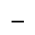 & - & 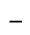 & t & - & - & - & + & & & & 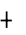 & - & - \\
\hline $3 \mathrm{MP} 4,50$ & - & - & - & - & + & . & - & - & - & - & - & - & - & - & BMP4, 50 & - & - & - & - & & . & - & & & & & 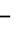 & - & - \\
\hline H & - & - & - & - & - & - & - & - & + & + & + & - & - & - & LF & - & - & - & - & - & - & - & - & & & & + & - & - \\
\hline $\mathrm{SH}$ & - & - & - & - & - & - & - & - & - & - & - & $t$ & + & + & FSH & - & - & - & - & - & - & - & - & & & & - & $t$ & $t$ \\
\hline
\end{tabular}

C. F1

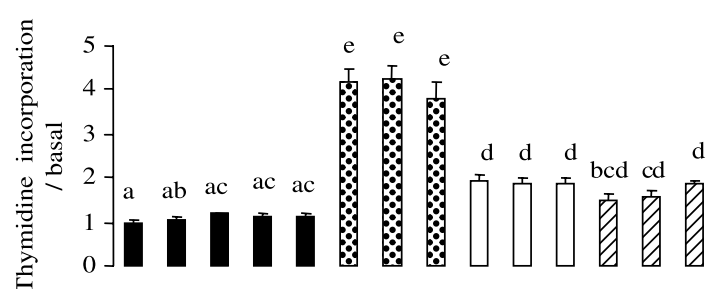

$\begin{array}{lllllllllllllll}\text { BMP15, 200 } & - & + & - & - & - & - & - & - & - & - & - & - & - & - \\ \text { BMP15, 50 } & - & - & + & - & - & - & + & - & - & + & - & - & + & - \\ \text { BMP4, 5 } & - & - & - & + & - & - & - & + & - & - & + & - & - & + \\ \text { BMP4, 50 } & - & - & - & - & + & - & - & - & - & - & - & - & - & - \\ \text { IGF-1 } 60 \% & - & - & - & - & - & + & + & + & - & - & - & - & - & - \\ \text { LH } & - & - & - & - & - & - & - & - & + & + & + & - & - & - \\ \text { FSH } & - & - & - & - & - & - & - & - & - & - & - & + & + & +\end{array}$

Figure 8 Effects of BMP15 on proliferation rate of cultured hen GCs. Thymidine incorporation was determined in GCs from F3/4, F2, and $\mathrm{F} 1$ preovulatory follicles cultured for $24 \mathrm{~h}$ in the presence or absence of IGF-I $\left(10^{-8} \mathrm{M}\right), \mathrm{LH}\left(10^{-8} \mathrm{M}\right)$, or FSH $\left(10^{-8} \mathrm{M}\right)$ with the combination of BMP15 (50 or $200 \mathrm{ng} / \mathrm{ml})$ or BMP4 $(5$ or $50 \mathrm{ng} / \mathrm{ml})$ as described in Materials and Methods. Results are representative of at least three independent experiments. The results are expressed as means \pm s.E.M. in relation to values in the absence of treatment (basal state). Different letters indicate that difference was significant $(P<0 \cdot 05)$. Seven independent experiments were performed in triplicate.

these factors act as modulators of gonadotropin action on hen GCs, as previously observed in the rat (Huang et al. 2001) but not in the sheep (Campbell et al. 1995). In addition, a study on rat ovarian theca cells showed that IGF-I alone did not stimulate androstenedione production and had only an effect when used in combination with other factors (Huang et al. 2001). In the present study, a strong inhibitory effect of BMP15 on LH-induced progesterone secretion was observed at all maturation stages. Such effects of BMPs have previously been reported on basal and $\mathrm{LH}$-induced androgen production in bovine theca interna cells (Glister et al. 2005). Moreover, the fact that we studied follicles a few days before ovulation $(60,36$, and $12 \mathrm{~h}$ before ovulation) might explain such a high sensitivity of GCs to LH action. An inhibitory effect was also observed in FSH-stimulated conditions for F3/4 and F2 stages. These BMP15 inhibitory effects were associated with a marked decrease in StAR expression in LH- and FSH-stimulated conditions. These effects associated with the increase of Smad phosphorylation showed that recombinant human BMP15 is biologically active on hen GCs. The BMP15 inhibitory effect on
FSH action in GCs has been widely documented in mammals (Otsuka et al. 2000, Su et al. 2004, McNatty et al. 2005). The absence of effect of BMP15 on FSH-induced progesterone secretion could be explained by a relatively low level of FSH receptor (FSHr) expression in the F1 follicles. In particular, in rat GCs, BMP15 was shown to inhibit FSH action by suppressing FSHr expression (Otsuka et al. 2001). It is of note that FSHr mRNA concentration is lower in F1 GCs than in smaller follicles (Yamamura et al. 2001). It would be interesting to investigate whether the effect of BMP15 on GC progesterone secretion is associated with a modulation of $\mathrm{LH}$ or FSH receptor expression, and/or with cAMP production level.

The steroidogenic enzymes 3 $\beta$-HSD, P450scc, and StAR were studied to investigate whether the inhibitory effect of BMP15 was due to a decrease in their expression (Otsuka et al. 2001). The only significant difference was obtained with StAR. Combined treatment with BMP15 (or BMP4) and LH (or FSH) caused a decrease in progesterone secretion as well as a decrease in StAR protein level. This combined treatment did not affect $3 \beta-H S D$ or P450scc expression, but could 
possibly affect their activity. The activities of these enzymes should be investigated in order to elucidate the mechanism of BMP15 action on hen GCs.

One interesting finding in this study was, in contrast to mammals, the absence of effect of BMP15 on GC proliferation. As a positive control, we verified that our GCs were able to proliferate in our in vitro conditions, IGF-I exerting in particular a strong mitogenic effect on these cells. It is possible that, as suggested by Juengel et al. (2006), which compared the effects of other BMPs from different mammalian species, human recombinant BMP15 that we used is not fully efficient on chicken cells, due to the relatively low percentage of identity $(72 \%)$ between BMP15 sequence of both species. It is also possible, as suggested by McNatty et al. (2005), that the presence of GDF9 is necessary for BMP15 to exert biological effect on proliferation of hen GCs. Of note, there was a significant inhibitory effect of BMP15 on proliferation of FSH-stimulated F3/4 GCs (1.7-fold less). It is therefore possible that, unlike mammalian species, there is only a slight or no effect of BMP15 on chicken GC proliferation.

In the present study, BMP4 and BMP15 presented similar effects on progesterone production and proliferation. In mammals, the effects of BMP15 and BMP4 have already been identified on progesterone secretion and GC proliferation. Both proteins have an inhibitory effect on progesterone secretion. The stimulatory effect of BMP4 on GC proliferation depends on the model studied (rat versus sheep; Juengel et al. 2006). Such a similar effect could reveal redundant molecules, produced in order to achieve essential functions.

Our BMP4 results differ from those of Onagbesan et al. (2003) reporting an intense stimulatory effect of BMP4 on LH-, FSH-, and/or IGF-I-induced progesterone secretion and on FSH- and/or IGF-I-induced proliferation. It is of note that BMP4 is known to be a potent inhibitor of progesterone secretion by GCs in every mammal studied (Pierre et al. 2004). In our study, BMP4 had almost the same effect as BMP15 on progesterone secretion and proliferation. One explanation for the differences between the two studies could be that the culture conditions were different. In the study of Onagbesan et al. (2003), M199 medium was used and the total culture period was longer $(72 \mathrm{~h})$ than in the present work (32 h; Onagbesan et al. 2003).

Previous studies have already shown that GDR destruction suppresses follicular maturation and ovulation and leads to atresia (Yoshimura et al. 1994, Yao et al. 1998). In addition, GDR produces proliferation-stimulating and steroidogenesisinhibiting factors that influence GCs (Tischkau \& Bahr 1996). In the present study, we showed that Bmp 15 was expressed by the oocyte, and recombinant BMP15 had a strong inhibitory effect on gonadotropin-stimulated progesterone secretion. The high similarity between human recombinant and chicken BMP15 could partially explain the similar effect of BMP15 on progesterone in rat and hen GCs (Otsuka et al. 2000). Overall, these findings suggest that BMP15 might be used by the oocyte together with other factors as EGF and GDF9 to modulate GC differentiation and progesterone production. EGF, also produced in the germinal disc, stimulates proliferation and decrease basal progesterone production (Volentine et al. 1998), and GDF9 was reported to stimulate proliferation (Johnson et al. 2005). The fact that in chicken, BMP15 has a similar expression pattern and in part similar effects on GCs as in mammals, provides strong evidence of the conserved essential role of BMP15 in the ovarian function in mammals and birds. Moreover, GDF9 has a similar expression pattern in the chicken and in mammals, and it enhances GC proliferation (Johnson et al. 2005). We hypothesize that BMP15 and GDF9 play an essential role in the regulation of the ovulation rate, normal follicular development and female fertility in the hen as in mammals (Dong et al. 1996, Yan et al. 2001, Hanrahan et al. 2004, Fabre et al. 2006). Future studies should investigate whether Bmp 15 and Gdf9 expression is associated with ovulation rate or multiple ovulations, using hen lines with different fertility parameters.

\section{Acknowledgements}

We thank Stéphane Fabre for helpful discussion and Frederic Mercerand and Jean-Didier Terlot-Bryssine for expert animal care. This study was supported by the 'Institut National de la Recherche Agronomique'. S E was supported by a fellowship from the Institut National de la Recherche Agronomique and 'Région Centre'. The authors declare that there is no conflict of interest that would prejudice the impartiality of this scientific work.

\section{Funding}

This study was supported by the 'Institut National de la Recherche Agronomique'. S E was supported by a fellowship from the Institut National de la Recherche Agronomique and 'Région Centre'.

\section{References}

Aaltonen J, Laitinen MP, Vuojolainen K, Jaatinen R, Horelli-Kuitunen N, Seppa L, Louhio H, Tuuri T, Sjoberg J, Butzow R et al. 1999 Human growth differentiation factor 9 (GDF-9) and its novel homolog GDF-9B are expressed in oocytes during early folliculogenesis. Journal of Clinical Endocrinology and Metabolism. 84 2744-2750.

Balemans W \& Van Hul W 2002 Extracellular regulation of BMP signaling in vertebrates: a cocktail of modulators. Developmental Biology 250 231-250.

Bodensteiner KJ, Clay CM, Moeller CL \& Sawyer HR 1999 Molecular cloning of the ovine Growth/Differentiation factor-9 gene and expression of growth/differentiation factor-9 in ovine and bovine ovaries. Biology of reproduction $60381-386$

Bodensteiner KJ, McNatty KP, Clay CM, Moeller CL \& Sawyer HR 2000 Expression of growth and differentiation factor- 9 in the ovaries of fetal sheep homozygous or heterozygous for the inverdale prolificacy gene (FecX(I)). Biology of reproduction 62 1479-1485. 
Campbell BK, Scaramuzzi RJ \& Webb R 1995 Control of antral follicle development and selection in sheep and cattle. Journal of Reproduction and Fertility 49 335-350.

Dong J, Albertini DF, Nishimori K, Kumar TR, Lu N \& Matzuk MM 1996 Growth differentiation factor-9 is required during early ovarian folliculogenesis. Nature 383 531-535.

Duffy DM 2003 Growth differentiation factor- 9 is expressed by the primate follicle throughout the periovulatory interval. Biology of reproduction 69 725-732.

Eckery DC, Whale LJ, Lawrence SB, Wylde KA, McNatty KP \& Juengel JL 2002 Expression of mRNA encoding growth differentiation factor 9 and bone morphogenetic protein 15 during follicular formation and growth in a marsupial, the brushtail possum (Trichosurus vulpecula). Molecular and cellular endocrinology 192 115-126.

Eric MT, Legouy E \& Renard J-P 1998 Mouse embryos do not wait for the MBT: Chromatin and RNA polymerase remodeling in genome activation at the onset of development. Developmental Genetics 22 31-42.

Etches RJ \& Petitte JN 1990 Reptilian and avian follicular hierarchies: models for the study of Ovarian Development. Journal of Experimental Zoology 4 $112-122$.

Fabre S, Pierre A, Mulsant P, Bodin L, Di Pasquale E, Persani L, Monget P \& Monniaux D 2006 Regulation of ovulation rate in mammals: contribution of sheep genetic models. Reproductive of Biology and Endocrinology 420.

Fitzpatrick SL, Sindoni DM, Shughrue PJ, Lane MV, Merchenthaler IJ \& Frail DE 1998 Expression of growth differentiation factor-9 messenger ribonucleic acid in ovarian and nonovarian rodent and human tissues. Endocrinology 139 2571-2578.

Galloway SM, McNatty KP, Cambridge LM, Laitinen MP, Juengel JL, Jokiranta TS, McLaren RJ, Luiro K, Dodds KG, Montgomery GW et al. 2000 Mutations in an oocyte-derived growth factor gene (BMP15) cause increased ovulation rate and infertility in a dosage-sensitive manner. Nature Genetics 25 279-283.

Gilbert AB 1971 The ovary. In Physiology and Biochemistry of the Domestic fowl, Eds DJ Bell \& BM Freeman. New York: Academic press.

Glister C, Richards SL \& Knight PG 2005 Bone morphogenetic proteins (BMP) $-4,-6$, and -7 potently suppress basal and luteinizing hormoneinduced androgen production by bovine theca interna cells in primary culture: could ovarian hyperandrogenic dysfunction be caused by a defect in thecal BMP signaling? Endocrinology 146 1883-1892.

Hanrahan JP, Gregan SM, Mulsant P, Mullen M, Davis GH, Powell R \& Galloway SM 2004 Mutations in the genes for oocyte-derived growth factors GDF9 and BMP15 are associated with both increased ovulation rate and sterility in Cambridge and Belclare sheep (Ovis aries). Biology of reproduction 70 900-909.

Hashimoto O, Moore RK \& Shimasaki S 2005 Posttranslational processing of mouse and human BMP-15: potential implication in the determination of ovulation quota. PNAS 102 5426-5431.

Huang ES \& Nalbandov AV 1979 Steroidogenesis of chicken granulosa and theca cells: in vitro incubation system. Biology of reproduction 20 442-453.

Huang CTF, Weitsman SR, Dykes BN \& Magoffin DA 2001 Stem cell factor and insulin-like growth factor-I stimulate luteinizing hormone-independent differentiation of rat ovarian theca cells. Biology of reproduction $\mathbf{6 4}$ 451-456.

Jaatinen R, Laitinen MP, Vuojolainen K, Aaltonen J, Louhio H, Heikinheimo K, Lehtonen E \& Ritvos O 1999 Localization of growth differentiation factor-9 (GDF-9) mRNA and protein in rat ovaries and cDNA cloning of rat GDF-9 and its novel homolog GDF-9B. Molecular and cellular endocrinology 156 189-193.

Johnson PA, Dickens MJ, Kent TR \& Giles JR 2005 Expression and function of growth differentiation factor-9 in an oviparous species. Gallus domesticus. Biology of reproduction 72 1095-1100.

Juengel JL, Hudson NL, Heath DA, Smith P, Reader KL, Lawrence SB, O'Connell AR, Laitinen MP, Cranfield M, Groome NP et al. 2002 Growth differentiation factor 9 and bone morphogenetic protein 15 are essential for ovarian follicular development in sheep. Biology of reproduction 67 $1777-1789$.
Juengel JL, Bodensteiner KJ, Heath DA, Hudson NL, Moeller CL, Smith P, Galloway SM, Davis GH, Sawyer HR \& McNatty KP 2004 Physiology of GDF9 and BMP15 signalling molecules. Animal Reproduction Science 82-83 447-460.

Juengel JL, Reader KL, Bibby AH, Lun S, Ross I, Haydon LJ \& McNatty KP 2006 The role of bone morphogenetic proteins 2, 4, 6 and 7 during ovarian follicular development in sheep: contrast to rat. Reproduction 131 501-513.

Knight PG \& Glister C 2003 Local roles of TGF-beta superfamily members in the control of ovarian follicle development. Animal Reproduction Science $\mathbf{7 8}$ 165-183.

Li H-K, Kuo T-Y, Yang H-S, Chen L-R, Li SS-L \& Huang H-W 2007 Differential gene expression of bone morphogenetic protein 15 and growth differentiation factor 9 during in vitro maturation of porcine oocytes and early embryos. Animal Reproduction Science In Press.

Malewska A \& Olszanska B 1999 Accumulation and localisation of maternal RNA in oocytes of Japanese quail. Zygote 7 51-59.

Marrone BL \& Hertelendy F 1983 Steroid metabolism by avian ovarian cells during follicular maturation. Biology of reproduction 29 953-962.

McNatty KP, Juengel JL, Reader KL, Lun S, Myllymaa S, Lawrence SB, Western A, Meerasahib MF, Mottershead DG, Groome NP et al. 2005 Bone morphogenetic protein 15 and growth differentiation factor 9 co-operate to regulate granulosa cell function. Reproduction 129 473-480.

Meirelles FV, Caetano AR, Watanabe YF, Ripamonte P, Carambula SF, Merighe GK \& Garcia SM 2004 Genome activation and developmental block in bovine embryos. Animal Reproduction Science Research and Practice III. 15th International Congress on Animal Reproduction 82-83 13-20.

Moore RK, Otsuka F \& Shimasaki S 2003 Molecular basis of bone morphogenetic protein-15 signaling in granulosa cells. Journal of Biolgical Chemistry 278 304-310.

Onagbesan OM, Bruggeman V, Van As P, Tona K, Williams J \& Decuypere E 2003 BMPs and BMPRs in chicken ovary and effects of BMP-4 and -7 on granulosa cell proliferation and progesterone production in vitro. American Journal of Physiology Endocrinology and Metabolism 285 E973-E983.

Otsuka F \& Shimasaki S 2002 A novel function of bone morphogenetic protein- 15 in the pituitary: selective synthesis and secretion of FSH by gonadotropes. Endocrinology 143 4938-4941.

Otsuka F, Yao Z, Lee T-h, Yamamoto S, Erickson GF \& Shimasaki S 2000 Bone morphogenetic protein-15. Identification of target cells and biological functions. Journal of Biolgical Chemistry 275 39523-39528.

Otsuka F, Yamamoto S, Erickson GF \& Shimasaki S 2001 Bone morphogenetic protein-15 inhibits follicle-stimulating Hormone (FSH) action by suppressing FSH receptor expression. Journal of Biolgical Chemistry 276 11387-11392.

Di Pasquale E, Beck-Peccoz P \& Persani L 2004 Hypergonadotropic ovarian failure associated with an inherited mutation of human bone morphogenetic protein-15 (BMP15) gene. American Journal of Human Genetics $\mathbf{7 5}$ 106-111.

Pennetier S, Uzbekova S, Perreau C, Papillier P, Mermillod P \& Dalbies-Tran R 2004 Spatio-temporal expression of the germ cell marker genes MATER, ZAR1, GDF9, BMP15, and VASA in adult bovine tissues, oocytes, and preimplantation embryos. Biology of reproduction 71 1359-1366.

Perry MM, Gilbert AB \& Evans AJ 1978 The structure of the germinal disc region of the hen's ovarian follicle during the rapid growth phase. Journal of Anatomy 127 379-392.

Pierre A, Pisselet C, Dupont J, Mandon-Pepin B, Monniaux D, Monget P \& Fabre S 2004 Molecular basis of bone morphogenetic protein-4 inhibitory action on progesterone secretion by ovine granulosa cells. Journal of Molecular Endocrinology 33 805-817.

Pierre A, Pisselet C, Dupont J, Bontoux M \& Monget P 2005 Bone morphogenetic protein 5 expression in the rat ovary: biological effects on granulosa cell proliferation and steroidogenesis. Biology of reproduction $\mathbf{7 3}$ $1102-1108$.

Sauveur B 1988 Reproduction des volailles et production des oeufs., Agronomique. Paris: Imprimerie Durand S.A.: INdIR.

Su YQ, Wu X, O’Brien MJ, Pendola FL, Denegre JN, Matzuk MM \& Eppig JJ 2004 Synergistic roles of BMP15 and GDF9 in the development and function of the oocyte-cumulus cell complex in mice: genetic evidence for an oocyte-granulosa cell regulatory loop. Developmental Biology 276 64-73. 
Tischkau SA \& Bahr JM 1996 Avian germinal disc region secretes factors that stimulate proliferation and inhibit progesterone production by granulosa cells. Biology of reproduction 54 865-870.

Tosca L, Froment P, Solnais P, Ferre P, Foufelle F \& Dupont J 2005 Adenosine $5^{\prime}$-monophosphate-activated protein kinase regulates progesterone secretion in rat granulosa cells. Endocrinology 146 4500-4513.

Tosca L, Crochet S, Ferre P, Foufelle F, Tesseraud S \& Dupont J 2006 AMP-activated protein kinase activation modulates progesterone secretion in granulosa cells from hen preovulatory follicles. Journal of Endocrinology 190 85-97.

Vitt UA, Hayashi M, Klein C \& Hsueh AJ 2000 Growth differentiation factor9 stimulates proliferation but suppresses the follicle-stimulating hormoneinduced differentiation of cultured granulosa cells from small antral and preovulatory rat follicles. Biology of reproduction 62 370-377.

Volentine KK, Yao HH \& Bahr JM 1998 Epidermal growth factor in the germinal disc and its potential role in follicular development in the chicken. Biology of reproduction 59 522-526.

Yamaguchi A 1995 Regulation of differentiation pathway of skeletal mesenchymal cells in cell lines by transforming growth factor-beta superfamily. Seminars in Cell Biology 6 165-173.

Yamamura N, Takeishi M, Goto H, Tagami M, Mizutani T, Miyamoto K, Doi O \& Kamiyoshi M 2001 Expression of messenger RNA for gonadotropin receptor in the granulosa layer during the ovulatory cycle of hens. Comparative Biochemistry and Physiology. Part A. Molecular \& Integrative Physiology 129 327-337.

Yao HH \& Bahr JM 2001 Chicken granulosa cells show differential expression of epidermal growth factor (EGF) and luteinizing hormone (LH) receptor messenger RNA and differential responsiveness to EGF and LH dependent upon location of granulosa cells to the germinal disc. Biology of reproduction 64 1790-1796.

Yan C, Wang P, DeMayo J, DeMayo FJ, Elvin JA, Carino C, Prasad SV, Skinner SS, Dunbar BS, Dube JL et al. 2001 Synergistic roles of bone morphogenetic protein 15 and growth differentiation factor 9 in ovarian function. Molecular Endocinology 15 854-866.

Yao HH, Volentine KK \& Bahr JM 1998 Destruction of the germinal disc region of an immature preovulatory chicken follicle induces atresia and apoptosis. Biology of reproduction $\mathbf{5 9}$ 516-521.

Yoshimura Y, Tischkau SA \& Bahr JM 1994 Destruction of the germinal disc region of an immature preovulatory follicle suppresses follicular maturation and ovulation. Biology of reproduction 51 229-233.

Yoshimura Y, Ando M, Nagamatsu S, Iwashita M, Adachi T, Sueoka K, Miyazaki T, Kuji N \& Tanaka M 1996 Effects of insulin-like growth factor-I on follicle growth, oocyte maturation, and ovarian steroidogenesis and plasminogen activator activity in the rabbit. Biology of reproduction $\mathbf{5 5}$ 152-160 (10.1095/biolreprod55.1.152).

Zagris N, Kalantzis K \& Guialis A 1998 Activation of embryonic genome in chick. Zygote 6 227-231.

Received in final form 25 June 2007

Accepted 26 June 2007

Made available online as an Accepted Preprint 29 June 2007 